Piotr Jać

Uniwersytet $w$ Biatymstoku

Karolina Zapolska

Uniwersytet w Biatymstoku

\title{
WSPOMAGANIE ZARZAQDZANIA \\ ZRÓWNOWAŻONYM ROZWOJEM \\ POLSKICH METROPOLII PRZY WYKORZYSTANIU NARZĘDZI „MIASTA INTELIGENTNEGO”
}

\section{Wprowadzenie}

Niniejszy artykuł omawia koncepcję „miasta inteligentnego” (ang. smart city), będącą jednym ze współczesnych sposobów parametryzacji metropolii i zarządzania ich rozwojem. Duże miasta stanowią z jednej strony rozbudowane jednostki osadnicze i złożone organizmy gospodarcze, których badanie i opisywanie wymaga interdyscyplinarnych narzędzi. Z drugiej - co do zasady są to podstawowe jednostki podziału administracyjnego, zarządzane przez lokalne wspólnoty samorządowe. Koncepcja smart city została scharakteryzowana w ujęciu i na tle doktrynalnym, przede wszystkim w kontekście zasady zrównoważonego rozwoju, a także w odniesieniu do współczesnego polskiego porządku prawnego: wybranych przepisów prawa administracyjnego, regulującego funkcjonowanie samorządów lokalnych.

Celem tak skonstruowanej analizy jest poszukiwanie odpowiedzi na pytanie, czy w polskich warunkach filozofia „miasta inteligentnego" może pozwalać na efektywne godzenie różnorodnych wartości i interesów występujących w środowisku miejskim, takich jak oczekiwania mieszkańców dotyczące jakości życia na obszarze zurbanizowanym, wyzwania związane $\mathrm{z}$ rozwojem gospodarczym miasta oraz prawne zobowiązania miejskich wspólnot politycznych, dotyczące w szczególności realizacji zasady zrównoważonego rozwoju.

Miasto stanowi złożony i skomplikowany organizm, na który składa się szereg różnych systemów, a ich wzajemne występowanie i istniejące między nimi zależności wymagają stworzenia efektywnego modelu ich interakcji. ${ }^{1}$ Jednocześnie miasto

1 R. Nierebiński, M. Fereniec, H. Pawlak, Skutki społeczno-ekonomiczne Future Internet, Gdańsk 2010, s. 152. 
jest dynamiczną, ewoluującą w czasie i przestrzeni strukturą zależności występujących na określonym obszarze. ${ }^{2}$ Równocześnie zauważa się wzrastające tempo urbanizacji oraz coraz większy przypływ ludności do dużych jednostek osadniczych, w których koncentruje się życie społeczne i gospodarcze. Stwarza to nowe wyzwania dla administracji publicznej.

Obecnie miasta i działające na ich obszarze organy władz publicznych muszą borykać się nie tylko z przestarzałą infrastrukturą niedostosowaną do potrzeb współczesnego społeczeństwa, stale rosnącymi oczekiwaniami społeczności lokalnych czy niedoborem dostępnych zasobów, ale także ze znacznym zanieczyszczeniem środowiska naturalnego i produkcją odpadów na dużą skalę. ${ }^{3}$ Ponadto są zobligowane, aby zmierzyć się z problemem przeludnienia oraz podołać wyzwaniom polityki klimatycznej. Nieodzowne staje się też podjęcie działań zmierzających do zwiększenia wydajności i funkcjonalności korzystania przez miasta z energii w każdej dziedzinie.

Koncepcję smart city - czyli „miasta inteligentnego" - uważa się za jeden z modeli wychodzących naprzeciw wspomnianym trudnościom. Idea ta zakłada tworzenie miasta zrównoważonego, co w podstawowym wymiarze sprowadza się do wykreowania przestrzeni przyjaznej dla jego mieszkańców. ${ }^{4}$ Jest to ujęcie interdyscyplinarne, w którym istotne znaczenie przypada zarówno badaniom humanistyczno-społecznym, jak i technicznym.

Jednocześnie idea inteligentnego zarządzania stanowi priorytetowy projekt w sektorze energetyki w Unii Europejskiej, której jednym z priorytetów jest osiągnięcie optymalizacji w zakresie wykorzystywania energii. ${ }^{5}$ Uwzględnia przy tym podstawowe postanowienia pakietu klimatyczno-energetycznego oraz wspiera zarządzanie zrównoważonym rozwojem miast. ${ }^{6}$ Jest skoordynowanym i kompleksowym zbiorem działań, który ma umożliwić osiąganie stałego rozwoju ekonomicznego przy jednoczesnym poszanowaniu środowiska naturalnego.

\section{Pojęcie i cele koncepcji smart cities}

Jak zostało zasygnalizowane, miasta muszą obecnie podołać wielu trudnościom rozwojowym i wynikającym stąd wyzwaniom dla administracji publicznej. Należą do nich m.in. wzrastające oczekiwania w stosunku do infrastruktury, wzrost zużycia

2 P. Żuber, Terytorialny wymiar w polityce rozwoju - potrzeba zmian systemowych w świetle nowej generacji dokumentów planistycznych, (w:) T. Markowski, P. Żuber (red.), System planowania przestrzennego i jego rola w strategicznym zarządzaniu rozwojem kraju, seria „Studia KPZK PAN” 2011, t. CXXXIV, s. 7-24.

3 M. Jarzemska, A. Węglarz, M. Wielomska, Zrównoważone miasto - zrównoważona energia z perspektywy energetyki przyjaznej środowisku, Warszawa 2011, s. 5.

4 S. Dolecki, Miasto, które myśli o swoich mieszkańcach, „Dzisiaj Magazyn dla klientów ABB w Polsce” 2013, nr 1/13(43), s. 23-24.

5 P. Markiewicz, Mapy drogowe jako instrument przekazywania wizji rozwoju, „Małopolskie Studia Regionalne” 2012, nr 1-2/24-25, s. 92-93.

6 M. Wdowiarz-Bliska, Od miasta naukowego do smart city, „Czasopismo Techniczne. Architektura” 2012, z. 1, online: https://suw.biblos.pk.edu.pl/resources/i1/i2/i3/i1/i5/r12315/WdowiarzBilskaM_MiastaNaukowego.pdfs, (data dostępu: 23.04.2013 r.), s. 307. 
energii, potrzeba przyciągania nowych inwestorów, a także pobudzanie wzrostu gospodarczego. W zakresie ochrony środowiska naturalnego miasta ponadto zmagają się z wysokim poziomem hałasu, dużym ruchem drogowym, nadmiernym zużyciem wody i niską jakością powietrza. ${ }^{7}$

Miasta europejskie są również zobowiązane do uwzględniania w swoich działaniach postanowień pakietu klimatyczno-energetycznego. Wiąże się z nim reguła „3x20\%”, czyli osiągnięcie do 2020 r. redukcji emisji $\mathrm{CO}_{2}$ o 20\%, zwiększenie udziału odnawialnych źródeł energii o $20 \%$ oraz wzrost efektywności energetycznej, a w związku z tym spadek zużycia energii - także o $20 \%{ }^{8}$

Należy przy tym mieć na uwadze, że miasta stanowią układy zbudowane w oparciu o współistnienie różnego typu systemów oraz przenikające się procesy gospodarcze i społeczne, w ramach których często może dochodzić do konfliktów interesów. ${ }^{9}$ Aby zapewnić efektywne funkcjonowanie tak złożonej struktury konieczne staje się wypracowanie reguł współdziałania między wieloma, często skrajnie różnymi podmiotami. Niezbędna staje się zatem inteligentna współpraca, polegająca na kooperacji między różnymi partnerami - organami administracji publicznej, przedsiębiorcami oraz społecznością lokalną.

Odpowiedzią na te trudności wydaje się koncepcja miasta inteligentnego (ang. smart city). „Smart” rozumianego jako struktura inteligentna, a także elastycznie i stosunkowo szybko reagująca na zmiany i nowe potrzeby lokalne. ${ }^{10}$ Koncepcja zakłada przy tym uwzględnianie istniejących uwarunkowań i możliwych potencjałów lokalnych, a także specyfiki miasta. Ocenia się ją jako odbicie nowoczesnego podejścia do kwestii związanych z zarządzaniem i przeobrażaniem się miast. ${ }^{11}$

Idea smart city sprowadza się do położenia akcentu na to, aby w ramach przestrzeni miejskiej posiadane zasoby i możliwości były wykorzystywane efektywniej. ${ }^{12}$ Dotyczy to zwłaszcza problematyki związanej z energią, bezpieczeństwem publicznym, transportem czy też ochroną środowiska naturalnego. ${ }^{13}$ Swoim zakresem odnosi się niemal do każdej sfery życia mieszkańców, zmierzając m.in. do wy-

7 L. Mierzejska, Zrównoważony rozwój miasta: aspekty planistyczne, Seria „Rozwój Regionalny i Polityka Regionalna" 2008, nr 5, s. 55.

8 Europa 2020. Strategia na rzecz inteligentnego i zrównoważonego rozwoju sprzyjającego włączeniu społecznemu, Komunikat Komisji, Bruksela 2010, s. 12.

9 T. Skoczkowski, Smart city - nowy element lokalnej polityki energetycznej, Krajowa Agencja Poszanowania Energii S.A. Instytut Techniki Cieplnej, Politechnika Warszawska, Ogólnopolska Konferencja „Energia dla inteligentnych miast - smart grid lokalnie i w regionach" w dniu 24 czerwca 2010 r. w Warszawie, online: http://www.ure. gov.pl/download.php?s=1\&id=3074 (data dostępu: 25.04 .2013 r.), s. 32.

10 T. Parteka, Inteligentny rozwój miast. Fantom czy trwały paradygmat?, (w:) A. Kukliński, J. Woźniak (red.), Unia Europejska. Dylematy XXI wieku, Kraków 2011, s. 178.

11 M. Mazerant (red.), Inteligentne miasta, „Biuletyn Informacyjny Regionalnego Programu Operacyjnego Województwa Łódzkiego na lata 2007-2013" 2012, nr 2, s. 6.

12 T. Parteka, Inteligentny rozwój miast. Fantom czy trwały paradygmat?, op. cit., s. 180-181.

13 57. Forum „Energia - Efekt - Środowisko”. Miasta przyszłości. Wybrane wypowiedzi i artykuły prasowe, Narodowy Fundusz Ochrony Środowiska i Gospodarki Wodnej, Warszawa 2013, online: http://forumees.pl/gfx/ees/ userfiles/files/57_forum/miasta.pdf (data dostępu: 23.04.2013 r.), s. 3. 
pracowania skutecznej współpracy władz i mieszkańców. ${ }^{14}$ „Inteligencja” mobilizuje miasta do korzystania z najnowszych technologii oraz wykorzystywania potencjału ich społeczności lokalnej. ${ }^{15}$ Ponadto jest ukierunkowana na osiąganie założeń zrównoważonego rozwoju, a tym samym stałe podnoszenie jakości środowiska naturalnego. ${ }^{16}$ Skuteczna realizacja idei smart city wymaga zatem zintegrowanych działań, wykorzystywania nowych technologii, zaangażowania obywateli oraz stworzenia odpowiednich procedur zarządzania miastem. ${ }^{17}$

Idea „miasta inteligentnego" składa się z szeregu komponentów, odpowiadających różnym obszarom funkcjonowania jednostki osadniczej. Wśród nich stosunkowo najczęściej wymienia się: 1) „inteligentną” ekonomię (ang. smart economy), 2) ,inteligentny" transport (ang. smart mobility), 3) ,inteligentne" środowisko (ang. smart environment), 4) ,inteligentnych” mieszkańców (ang. smart people), 5) ,inteligentne" warunki życia (ang. smart living) oraz 6) ,inteligentne” zarządzanie publiczne (ang. smart governance). ${ }^{18}$

Pod pojęciem smart economy kryją się takie działania i wartości, jak promowanie innowacyjności, przedsiębiorczość, dążenie do zwiększania konkurencyjności miasta, a także elastyczność rynku pracy. ${ }^{19} \mathrm{~W}$ zakresie wskaźników smart people nacisk kładzie się na inwestowanie w kapitał społeczny i ludzki: podnoszenie kwalifikacji, promowanie kreatywności, uwzględnianie zróżnicowań społeczno-kulturowych i zachęcanie mieszkańców miast do aktywnej partycypacji w życiu publicznym. ${ }^{20} \mathrm{~W}$ tej sferze szczególne znaczenie ma włączanie w procesy decyzyjne podmiotów obecnych w przestrzeni danego miasta. Dużą rolę odgrywa tu usprawnienie procesu wymiany informacji między uczestnikami współpracy oraz pozostałymi aktorami procesów społeczno-politycznych.

Smart governance wiąże się $\mathrm{z}$ przejrzystością zarządzania, wprowadzania w życie wspomnianych już koncepcji zarządzania opartych na współpracy władz i mieszkańców, a także prowadzeniem działań administracji publicznej w oparciu o strategie - przemyślane, interdyscyplinarne, średnio- i długoterminowe polityki, opracowywane z udziałem ekspertów oraz konsultowane z członkami lokalnej społeczności. ${ }^{21}$ Smart mobility to przede wszystkim tworzenie i zwiększanie dostępu do infrastruktury ICT, a także wprowadzanie zrównoważonych i bezpiecznych systemów transportowych. W tym kontekście zwraca się uwagę na propagowanie ener-

14 E. Węcławowicz-Bilska, Miasto przyszłości - tendencje, koncepcje, realizacje, „Czasopismo Techniczne. Architektura” 2012, z. 1, online: http://suw.biblos.pk.edu.pl/resources/i1/i2/i3/i1/i7/r12317/WeclawowiczBilskaE_MiastoPrzyszlosci.pdf (data dostępu: 25.04.2013 r.), s. 326.

15 K. Krysztofiak, Krakowski Park Technologiczny: w poszukiwaniu inteligentnej specjalizacji dla Małopolski, „Małopolskie Studia Regionalne" 2012, nr 1-2/24-25, s. 76.

16 R. Nierebiński, M. Fereniec, H. Pawlak, Skutki społeczno-ekonomiczne..., op. cit., s. 153.

17 M. Wdowiarz-Bliska, Od miasta naukowego do smart city, op. cit., ss. 307-308.

18 P. Markiewicz, Mapy drogowe jako instrument..., op. cit., s. 93.

19 S. Dolecki, Miasto, które myśli o swoich mieszkańcach, „Dzisiaj - Magazyn dla klientów ABB w Polsce” 2013, nr 1/13(43), styczeń-marzec 2013, s. 24.

20 Ibidem, s. 23-24

21 R. Nierebiński, M. Fereniec, H. Pawlak, Skutki społeczno-ekonomiczne..., op. cit., s. 153. 
gooszczędnych i prośrodowiskowych środków transportu, a także racjonalizację wykorzystywania samochodów przez mieszkańców - zarówno pojazdów osobowych, jak i ciężarowych. ${ }^{22}$

„Inteligentne” środowisko, tj. smart environment opisuje środowisko przyrodnicze miasta funkcjonujące w oparciu o inteligentne metody działalności człowieka, w co wpisuje się m.in. promocja atrakcyjności warunków przyrodniczych, walka z zanieczyszczeniami oraz zrównoważone zarządzanie zasobami naturalnymi. ${ }^{23}$ Sfera smart living obejmuje różnorodne czynniki wpływające na jakość życia, komfort korzystania z przestrzeni miejskiej, dostępność usług publicznych oraz obiektywne bezpieczeństwo i subiektywne poczucie bezpieczeństwa mieszkańców. Ten szeroki obszar problemowy sprowadza się m.in. do rozbudowanej bazy obiektów kulturalnych i sportowych, sprawnego i nowoczesnego systemu opieki zdrowotnej, szerokiej oferty edukacyjnej oraz komfortu i bezpieczeństwa zamieszkania. ${ }^{24}$

Zwraca uwagę, że założeniem idei smart city jest osiąganie rozwoju gospodarczego, podnoszenie innowacyjności, poprawa stanu środowiska naturalnego oraz usprawnienie zarządzania miastem - przy jednoczesnym rozwijaniu jakości życia mieszkańców. W tym aspekcie pożądanym zachowaniem jest branie pod uwagę wszystkich czynników mających wpływ na funkcjonowanie miasta i próba ich udoskonalania w interesie wspólnoty lokalnej.

Końcowym efektem wprowadzenia założeń „miasta inteligentnego” ma być stworzenie miasta przyjaznego dla jego mieszkańców, czyli miasta zapewniającego wysoką jakość życia, a także sprawne funkcjonowanie podstawowych organów i instytucji. ${ }^{25}$ Przyjecie założeń smart w jednostce, jaką jest miasto ma przyczynić się m.in. do racjonalizowania zużycia energii, zmniejszenia emisji zanieczyszczeń, promowania recyklingu śmieci, utylizacji odpadów, zwiększania obszarów zieleni w przestrzeni miejskiej, usprawnienia infrastruktury komunikacyjnej, a także rozwoju życia kulturalnego. ${ }^{26}$ Priorytetowym celem opisywanej koncepcji jest zatem dążenie do optymalizacji i ulepszenia w szczególności w sferze energii, transportu, informacji czy też technologii komunikacyjnych. ${ }^{27}$

$\mathrm{Na}$ kontynencie europejskim koncepcja smart city nawiązuje do priorytetów programu Europa 2020. Strategia na rzecz inteligentnego i zrównoważonego rozwoju sprzyjającego włączeniu społecznemu ${ }^{28}$ oraz postanowień Agendy Terytorialnej Unii Europejskiej 2020 W kierunku sprzyjającej społecznemu włączeniu,

\footnotetext{
22 A. Mikłaszewski, Ekorozwój - rozwój zrównoważony, „Prace Naukowe Instytutu Górnictwa Politechniki Wrocławskiej. Studia i Materiały" 2000, vol. 87, nr 28, s. 45.

E. Węcławowicz-Bilska, Miasto przyszłości..., op. cit., s. 326.

S. Dolecki, Miasto, które myśli o swoich mieszkańcach, op. cit., s. 24.

Ibidem, s. 23-24.

T. Parteka, Inteligentny rozwój miast..., op. cit., s. 181.

Inicjatywa smart cities, Stowarzyszenie Pomorskie w Unii Europejskiej, online: http://bape.com.pl/LinkClick. aspx?fileticket=p23D6ranEaA\%3d\&tabid=433 (data dostępu: 24.04 .2013 r.), s. 1. 28 Komunikat Komisji z 3 marca 2010 r. EUROPA 2020 Strategia na rzecz inteligentnego i zrównoważonego rozwoju
sprzyjającego włączeniu społecznemu.
} 
inteligentnej i zrównoważonej Europy zróżnicowanych regionów, ${ }^{29}$ które wprowadzają pojęcie smart growth. ${ }^{30}$ Ów ,inteligentny rozwój” jest nawiązaniem i uzupełnieniem idei rozwoju zrównoważonego, w związku z którym podkreśla się ważkość problematyki ochrony środowiska naturalnego w kontekście działań związanych z gospodarką i przestrzenią (zwłaszcza jej zagospodarowaniem). ${ }^{31}$ Ideę miasta inteligentnego uważa się za przykład funkcjonowania przestrzeni miejskiej pozwalający na realizację priorytetów zarówno smart growth, jak i zrównoważonego rozwoju na poziomie regionalnym oraz miejskim. ${ }^{32}$

Warto podkreślić, iż smart city stanowi przy tym stosunkowo szeroką i zróżnicowaną koncepcję, która może być realizowana w różny sposób. Jej urzeczywistnienie może przybrać przykładowo formę platformy software'owej - systemu oprogramowania obejmującego swym działaniem całą infrastrukturę miejską.

Innym pomysłem na wprowadzenie w życie idei smart city jest opracowanie sieci inteligentnych podsystemów (ang. smart grid), którymi są sieci elektroenergetyczne funkcjonujące w oparciu o współpracę między wszystkimi jej uczestnikami, wykorzystującą narzędzia ICT. ${ }^{33}$ Przykładem miasta europejskiego realizującego działania opisane w powyższych strategiach, a jednocześnie korzystającego z rozwiązań mieszczących się w ramach koncepcji smart city, jest Amsterdam - realizujący aktualnie program „AmSMARTerdam city". ${ }^{34}$

\section{Koncepcja zrównoważonego rozwoju}

Nadmierna eksploatacja środowiska przyrodniczego oraz szybki przyrost ludności świata $\mathrm{w}$ latach 70 . XX w. zostały uznane za jeden $\mathrm{z}$ ważnych problemów, z którymi musi się zmierzyć ludzkość. Osiągnięcie harmonii między - często wzajemnie wykluczającymi się - wartościami: z jednej strony dążeniem do uzyskiwania wzrostu gospodarczego, a $\mathrm{z}$ drugiej potrzebą zachowania stanu środowiska naturalnego na stosunkowo wysokim poziomie, uznaje się za możliwe dzięki idei zrównoważonego rozwoju. ${ }^{35}$ Koncepcję tę uważa się za szansę na ochronę zasobów naturalnych z myślą o przyszłych pokoleniach poprzez racjonalne ich wykorzystywanie przez współczesnych.

Została przyjęta na nieformalnym spotkaniu ministrów ds. planowania przestrzennego i rozwoju terytorialnego 19 maja 2011 r. w Gödöllö na Węgrzech.

L. Mierzejewska, Smart growth jako model rozwoju miasta, (w:) J. Słodczyk, M. Śmigielska (red.), Współczesne kierunki i wymiary procesów urbanizacji, Opole 2008, s. 49-50.

T. Parteka, Inteligentny rozwój miast. Fantom czy trwały paradygmat?, op. cit., s. 182. Ibidem, s. 180-181.

A. Kowalska-Pyzalska, Koncepcja smart grid szansą dla rozwoju generacji rozproszonej, „Prace Naukowe Instytutu Maszyn, Napędów i Pomiarów Elektrycznych Politechniki Wrocławskiej. Studia i Materiały” 2011, vol. 65, nr 31, s. 444.

M. Pytliński, Amsterdam: kształtowanie modelu inteligentnego miasta przy udziale wytwarzania rozproszonego, (w:) J. Rączka, M. Swora, W. Stawiany (red.), Generacja rozproszona w nowoczesnej polityce energetycznej - wybrane problemy i wyzwania, Warszawa 2012, s. 105.

J. Ciechanowicz-McLean, Prawo i polityka ochrony środowiska, Warszawa 2013, s. 42. 
Zrównoważony rozwój jest wyrazem zasady głoszącej prawo przyszłych pokoleń do życia w zdrowym środowisku naturalnym oraz korzystania z zasobów naturalnych. Stanowi ona jednocześnie jedno z najważniejszych wyzwań w zakresie realizacji polityki na rzecz ochrony środowiska naturalnego, przed którym stoją państwa współczesne. ${ }^{36}$ Zasadę zrównoważonego rozwoju zalicza się do priorytetowych wartości w nowoczesnej polityce ochrony środowiska naturalnego.

Zrównoważony rozwój stanowi regułę, którą opracowano w licznych dokumentach o randze międzynarodowej oraz uściślono w doktrynie, a ostatecznie w ustawodawstwie większości państw. ${ }^{37}$ Dotychczas nie powstała jednak precyzyjna definicja tego pojęcia. ${ }^{38}$ Istota koncepcji zrównoważonego rozwoju sprowadza się do próby pogodzenia - często wzajemnie wykluczających się - potrzeb o charakterze społecznym, ekonomicznym i ekologicznym. ${ }^{39}$ Polega na wspomaganiu gospodarki efektywnie korzystającej z zasobów, przy uwzględnieniu potrzeb środowiska naturalnego oraz pobudzaniu jej konkurencyjności. ${ }^{40}$ Wskazuje na zależności między rozwojem ekonomicznym obywateli a stanem środowiska. ${ }^{41}$ Dąży do wypracowania harmonijnej relacji pomiędzy człowiekiem a przyrodą.

Koncepcja ta ściśle więc wiąże się z koniecznością ochrony środowiska naturalnego, a kwestie ekologiczne stanowią fundament zasady zrównoważonego rozwoju. ${ }^{42}$ Jej realizacja ma umożliwić zwiększenie jakości życia nie tylko obecnych, ale i przyszłych pokoleń, przy jednoczesnym zachowaniu środowiska naturalnego w jak najlepszym stanie. ${ }^{43}$ Dąży się tym samym do rozsądnego wykorzystywania dostępnych zasobów naturalnych, ograniczania zachowań uciążliwych dla środowiska oraz utrzymania różnorodności biologicznej. ${ }^{44} \mathrm{~W}$ związku z tym państwa są zobowiązane do uwzględniania zagadnień związanych z ochroną środowiska w trakcie podejmowanych przez siebie działań - na każdym z etapów procesów decyzyjnych. ${ }^{45}$

W kontekście niniejszej pracy podstawowe znaczenie ma zwłaszcza zrównoważony rozwój miast, który wydaje się kwestią szczególnie aktualną. Część doktryny uważa, że to właśnie skala miasta stanowi najlepszą i najwłaściwszą formę do urze-

36 L. Mierzejewska, Wskaźniki rozwoju zrównoważonego i różne podejścia do ich konstrukcji, (w:) J.J. Parysek, T. Stryjakiewicz (red.), Region społeczno-ekonomiczny i rozwój regionalny, Poznań 2008, s. 189-190.

W polskim porządku prawnym zrównoważony rozwój znajduje się m.in. w art. 5 Konstytucji RP i ma charakter zasady ustrojowej, Z. Bukowski, Konstytucyjne podstawy obowiązków państwa w zakresie ochrony środowiska, „Prawo i Środowisko” 2002, nr 4, s. 64-65.

38 E. Mazur-Wierzbicka, Miejsce zrównoważonego rozwoju w polskiej i unijnej polityce ekologicznej na początku XXI wieku, „Nierówności Społeczne a Wzrost Gospodarczy” 2006, z. 8, cz. 1, s. 317.

39 J. Kronenberg, T. Bergier, Wyzwania Zrównoważonego Rozwoju w Polsce, Warszawa 2010, ss. 217-218.

40 T. Parteka, Inteligentny rozwój miast..., op. cit., s. 176.

41 E. Mazur-Wierzbicka, Miejsce zrównoważonego rozwoju..., op. cit., s. 317.

42 A. Ciesielska, T. Poskrobko, Wpływ informacji na trwały i zrównoważony rozwój w warunkach gospodarki opartej na wiedzy, http://mikro.univ.szczecin.pl/bp/pdf/46/18.pdf (data dostępu: 24.04.2013 r.), ss. 3-5.

43 W. Radecki, Ustawa o odpadach: komentarz, Warszawa 2008, s. 65.

44 E. Mazur-Wierzbicka, Miejsce zrównoważonego rozwoju..., op. cit., s. 319.

45 J. Sozański, Standardy zrównoważonego rozwoju i wspólnotowej polityki ochrony środowiska na tle obowiązków państw kandydujących do Unii, (w:) K. Równy, J. Jabłoński (red.), Zasada zrównoważonego rozwoju w prawie i praktyce ochrony środowiska, Warszawa 2002, s. 92. 
czywistniania założeń zrównoważonego rozwoju. ${ }^{46}$ Miasto jest bowiem strukturą, w której sfera społeczna, gospodarcza, kulturowa oraz przyrodnicza współistnieją i są od siebie wzajemnie zależne. ${ }^{47}$ Ponadto podkreśla się olbrzymią presję, jaką wywiera funkcjonowanie przestrzeni miejskiej oraz działalność i życie jej mieszkańców na stan środowiska naturalnego. ${ }^{48}$

Skuteczna realizacja zrównoważonego rozwoju w systemie miasta wymaga przede wszystkim uwzględniania jego uwarunkowań, konieczności osiągania rozwoju gospodarczego, a także podejmowania działań zmierzających zarówno do poprawy środowiska naturalnego, jak i życia społeczności lokalnej. ${ }^{49}$

Szczególną rolę miast w kontekście zasady zrównoważonego rozwoju podkreśla zwłaszcza Karta Lipska, na podstawie której ustanowiono priorytet zrównoważonego rozwoju miast. ${ }^{50}$ Podkreśla ona przede wszystkim konieczność zintegrowanego podejścia do rozwoju miast oraz opracowywania strategii i działań dla kryzysowych obszarów miast. Wszystkie podejmowane w tym zakresie działania mają jednocześnie uwzględniać potrzebę podnoszenia jakości środowiska naturalnego.

Uzupełnieniem Karty Lipskiej są - Agenda Terytorialna Unii Europejskiej zarówno z 2007, ${ }^{51}$ jaki i 2011 roku $^{52}$ oraz Deklaracja z Toledo z 22 czerwca 2010 r. $^{53}$ Ich postanowienia uwzględniają wprowadzoną na mocy Traktatu Lizbońskiego potrzebę osiągnięcia spójności terytorialnej oraz bezpośrednio odnoszą się do regionów i miast, w tym obszarów metropolitalnych, miast średnich i mniejszych. ${ }^{54}$

\section{Koncepcja smart cities w świetle ustaw samorządowych}

W Polsce od 1998 r. obowiązuje trójstopniowy model podziału administracyjnego - na województwa samorządowe, ${ }^{55}$ powiaty ${ }^{56}$ i gminy. ${ }^{57}$ Wymaga podkreślenia, że zadania publiczne dotyczące miast mogą występować na każdym szczeblu samorządu terytorialnego. Największe polskie metropolie są w sensie ustrojowym poje-

46

47

48

49

50

51

L. Mierzejska, Zrównoważony rozwój miasta: aspekty planistyczne, op. cit., s. 49.

A. Drapella-Hermansdorfer, Wrocławskie Zielone Wyspy - projekt zarządzania zasobami Środowiska miejskiego, Wrocław 2003, s. 49.

L. Mierzejska, Zrównoważony rozwój miasta: aspekty planistyczne, op. cit., s. 53.

Ibidem.

Leipzig Charter on Sustainable European Cities - Karta Lipska w sprawie zrównoważonych miast europejskich, przyjęta przez Ministrów Państw Członkowskich UE w maju 2007 roku w Lipsku.

Agenda Terytorialna Unii Europejskiej przyjęta na Nieformalnym Spotkaniu Ministrów Państw Członkowskich UE ds. Spójności Terytorialnej i Rozwoju Miast 24-25 maja 2007 roku w Lipsku.

Agenda Terytorialna Unii Europejskiej 2020: W kierunku sprzyjającej społecznemu włączeniu, inteligentnej i zrównoważonej Europy zróżnicowanych regionów, Nieformalne Posiedzenie Ministrów ds. planowania przestrzennego i rozwoju terytorialnego, 19 maja 2011 roku w Gödöllö (Węgry).

M. Jarzemska, A. Węglarz, M. Wielomska, Zrównoważone miasto..., op. cit., s. 6-7.

L. Mierzejska, Zrównoważony rozwój miasta: aspekty planistyczne, op. cit., s. 49.

Ustawa z dnia 5 czerwca 1998 r. o samorządzie województwa; t.j. Dz.U. z 2001 r. Nr 142, poz. 1590 z późn. zm.

Ustawa z dnia 5 czerwca 1998 r. o samorządzie powiatowym; t.j. Dz.U. z 2001 r. Nr 142, poz. 1592 z późn. zm.

Ustawa z dnia 8 marca 1990 r. o samorządzie gminnym (w latach 1990-1998 nosiła tytuł ustawy o samorządzie terytorialnym); t.j. Dz.U. z 2001 r. Nr 142, poz. 1591 z późn. zm. 
dynczymi gminami, ${ }^{58}$ co oznacza, że prawne instrumenty zarządzania ich rozwojem są analogiczne do małych gmin wiejskich. Jednocześnie duże jednostki osadnicze posiadają status miast na prawach powiatu, co oznacza wykonywanie przez władze takich miast również zadań drugiego szczebla władz lokalnych. ${ }^{59}$ Zarazem problemy największych jednostek osadniczych - zwłaszcza miast wojewódzkich - stanowią istotny przedmiot zainteresowania samorządów regionalnych. ${ }^{60}$

Współcześnie zjawiska społeczne i gospodarcze związane z dużą jednostką osadniczą w naturalny i nie zawsze kontrolowany sposób ,rozlewają się” na gminy sąsiednie, tworząc uwarunkowania oraz problemy o skali aglomeracyjnej. ${ }^{61}$ Do ich diagnozy używano dotąd narzędzi wyodrębniających tzw. obszary metropolitalne; obecnie dokumenty publiczne częściej posługują się pojęciem „obszary funkcjonalne”. Również w ten sposób problemy polskich metropolii, które stanowią zarazem stolice województw i społeczno-ekonomiczne serca poszczególnych regionów, stają się problemami regionalnymi. ${ }^{62}$

Jak zaznaczono uprzednio, koncepcja smart city bierze pod uwagę kilka głównych obszarów problemowych: ekonomię, transport, środowisko, mieszkańców, warunki życia i zarządzanie publiczne. Z tej perspektywy prawnych uwarunkowań wprowadzania tej idei można doszukiwać się na przede wszystkim na szczeblu gminy.

Zgodnie z przepisami ustawy o samorządzie gminnym to na najniższym szczeblu samorządu terytorialnego spoczywa w Polsce domniemanie kompetencji (art. 6), przy czym zadania własne gmin są wymienione w obszernym katalogu, która ma otwarty charakter (art. 7). Jak się wydaje, w ogólnej kategorii ,zbiorowych potrzeb wspólnoty" lokalnej będą się mieściły wszystkie obszary ujęte w koncepcji smart city.

Zadaniom w zakresie inteligentnej ekonomii w poszczególnych miastach mogą odpowiadać następujące zakresy polityki gminy: gospodarka nieruchomościami, gospodarka wodna, utrzymanie czystości i porządku, a także targowiska i hale targowe. $^{63}$

58 Poza zakresem rozważań pozostaje kwestia tego, czy w ich organizacji występują pewne odrębności, np. związane ze statusem miasta stołecznego albo z wewnętrznym wyodrębnieniem jednostek pomocniczych, takich jak dzielnice, osiedla czy sołectwa.

59 Zob. art. 91 i n. ustawy o samorządzie powiatowym.

60 Tytułem przykładu można wskazać, że w perspektywie finansowej Unii Europejskiej na lata 2014-2020 w ramach polityki spójności realizowanej na poziomie regionalnym, przewidziano dodatkowe środki dla miejskich obszarów funkcjonalnych miast wojewódzkich (MOF OW) w ramach tzw. zintegrowanych inwestycji terytorialnych.

61 Związane jest z tym szersze niż zarysowana problematyka zjawisko eksurbanizacji (ang. urban sprawl), polegającej w najogólniejszym sensie na rozwoju przestrzennym (powierzchniowym) miast, przy jednoczesnym zacieraniu się granicy pomiędzy miastem a jego przedmieściami, otoczeniem i pozostałymi miejscowościami. Stąd metafora „rozlewania się miast”, która - jak należy sądzić - obrazuje istotę zjawiska.

62 To jedna z przyczyn, dla których w ramach Komisji Europejskiej funkcjonuje obecnie Dyrekcja Generalna ds. Polityki Regionalnej i Miejskiej, która zastąpiła dawną Dyrekcję Generalną ds. Polityki Regionalnej (DG REGIO).

63 Dla rozwoju lokalnej przedsiębiorczości i pozyskiwania inwestorów mają też znaczenie takie rozwiązania jak konstrukcja gminnych podatków i opłat lokalnych czy przywileje dla przedsiębiorców wynikające z prawa gospodarczego, podatkowego lub finansowego - co jednak pozostaje poza przedmiotem niniejszej analizy. 
Do działalności w sferze inteligentnego transportu mogą należeć z jednej strony sprawy obejmujące gminne drogi, ulice, mosty, place oraz organizacja ruchu drogowego, a z drugiej - transport zbiorowy. Nawet jeśli po stronie gminy nie będą $\mathrm{z}$ danego tytułu istniały żadne zobowiązania dotyczące prowadzenia określonej działalności (np. wobec braku własnego taboru obsługującego kolej podmiejską), to inteligentny transport może być źródłem wydatków ponoszonych na sprzęt czy usługi realizowane przez podmioty niepubliczne.

Inteligentne środowisko $\mathrm{w}$ świetle ustawy o samorządzie gminnym będzie mieściło się w takich sferach zadań, jak sprawy ładu przestrzennego, gospodarki nieruchomościami, ochrony środowiska i przyrody oraz gospodarki wodnej, utrzymanie czystości i porządku oraz urządzeń sanitarnych, wysypisk i unieszkodliwiania odpadów komunalnych, zieleni gminnej i zadrzewień, a niekiedy także sprawy związane z gminnymi cmentarzami.

Wspieranie sfery ,inteligentnych mieszkańców” może na poziomie zadań gminnych dotyczyć m.in. pomocy społecznej, wspierania rodziny i systemu pieczy zastępczej, porządku publicznego i bezpieczeństwa obywateli oraz ochrony przeciwpożarowej i przeciwpowodziowej, polityki prorodzinnej, współpracy i działalności na rzecz organizacji pozarządowych oraz podmiotów prowadzących działalność pożytku publicznego, a także współpracy ze społecznościami lokalnymi i regionalnymi innych państw.

Inteligentne warunki życia to kategoria, w której - jak należy sądzić - mieszczą się nie tylko zmienne skorelowane z konkretnymi obszarami zadań publicznych. Mimo to stosunkowo najmniej trudności zdaje się nastręczać powiązanie z jakością życia takich spraw lokalnych, jak ochrona zdrowia, działalność z zakresu gminnego budownictwa mieszkaniowego, edukacja publiczna, sprawy kultury, a także kwestie kultury fizycznej i turystyki.

Inteligentne zarządzanie publiczne może obejmować różnorodne działania lokalnych władz, a także zasady organizacji i pracy urzędów obsługujących organy samorządowe. Spośród zadań publicznych realizowanych przez samorząd gminny można tutaj wskazać kwestie utrzymania gminnych obiektów i urządzeń użyteczności publicznej oraz obiektów administracyjnych, wspierania i upowszechniania idei samorządowej czy wdrażania programów pobudzania aktywności obywatelskiej.

Należy zaznaczyć, że powyższe powiązania gminnych zadań publicznych z obszarami „inteligencji” miasta mają charakter ilustracyjny. Ich celem jest wskazanie, że w polskim ustroju realizacja idei smart city mieści się w sferze kompetencji władz publicznych oraz może być przypisana samorządom lokalnym, przede wszystkim gminom - na których spoczywają także liczne obowiązki dotyczące urzeczywistniania zrównoważonego rozwoju. 
Wspomaganie zarządzania zrównoważonym rozwojem polskich metropolii...

\section{Podsumowanie}

Jak wskazano powyżej, koncepcja „miasta inteligentnego” jest nową propozycją dotyczącą zarządzania rozwojem obszarów miejskich, uwzględniającą wiele sfer rozwoju organizmu miejskiego i różne obszary problemowe. Jest to koncepcja interdyscyplinarna - integrująca i pozwalająca na nowo usystematyzować priorytety polityki lokalnej.

$\mathrm{Z}$ uwagi na wpisanie w ideę smart city narzędzi oraz wskaźników dotyczących „inteligentnego" środowiska naturalnego (smart environment), może ona sprzyjać realizacji zasady zrównoważonego rozwoju. W tym kontekście inteligentny rozwój zrównoważony można rozumieć jako takie zarządzanie przestrzenią i zasobami naturalnymi na obszarach miejskich, które pozwala na maksymalizację ich obecnej użyteczności społecznej oraz gospodarczej, przy zachowaniu w stanie niepogorszonym z myślą o przyszłych pokoleniach, w tym z myślą o przyszłym rozwoju danej jednostki osadniczej.

W polskim systemie prawa realizacja koncepcji ,miasta inteligentnego" - w tym w zakresie dotyczącym środowiska naturalnego i rozwoju zrównoważonego - stanowi przede wszystkim zadanie samorządu gminnego. Nowym wyzwaniem, wykraczającym poza ramy niniejszego tekstu jest suburbanizacja, która przyczynia się do zatarcia granic pomiędzy miastem a obszarami podmiejskimi i w efekcie do przenikania zjawisk metropolitalnych do gmin ościennych, dysponujących często znacznie mniejszym potencjałem i zdolnością do zarządzania nimi. W tym zakresie zadania urzeczywistniania ideałów smart city wydają się spoczywać także na powiatach i województwach.

Należy ponadto zauważyć, że poszczególnym sferom miejskiej ,inteligencji”, które można usystematyzować w sześć głównych obszarów (ekonomię, transport, środowisko naturalne, mieszkańców, warunki życia oraz zarządzanie publiczne), można przyporządkować zadania publiczne wskazane w ustawie o samorządzie gminnym. Kolejne zadania należą do sfery działań organów powiatowych, regionalnych i państwowych, a w efekcie są uregulowane w innych aktach normatywnych.

W ocenie autorów idea ,miasta inteligentnego" stanowi interesującą i potencjalnie użyteczną koncepcję opisywania oraz projektowania nowoczesnego zarządzania rozwojem miast, zwłaszcza w odniesieniu do metropolii. Wspomniana filozofia może pozwalać na efektywne godzenie różnorodnych wartości i interesów występujących w środowisku miejskim. Wymaga zarazem podkreślenia, że ponieważ koncepcja smart cities jest nową ideą, liczne jej aspekty wymagają przeprowadzenia dalszych, interdyscyplinarnych badań. $Z$ powyższych przyczyn niniejsze rozważania należy traktować jedynie jako próbę nakreślenia zarysu opisanej problematyki. 


\section{SUPPORTING THE MANAGEMENT OF SUSTAINABLE DEVELOPMENT IN POLISH METROPOLISES WITH THE USE OF "SMART CITY" INSTRUMENTS}

The authors discuss the concept of "smart cities", which is one of the modern tools of city parameterization, hitherto used particularly in relation to metropolises of Western civilization. The analysis focuses on the relationship between the essentials of "smart" city management, as identified by the doctrine, and sustainable development, as well as selected legal conditions of applying this concept in the context of the Polish local government system and Polish administrative law. Due to the complexity of the concept of cites being "smart", a comprehensive study of this phenomenon has to go beyond legal issues and beyond the determinants of the public finance sector. However, the article does not address practical considerations and opinions presented are limited to discussion on legal and political system conditions. The text should be regarded as an attempt to identify some basic system factors of the issue in Poland and a basic contribution for further, more substantial and practical research.

Keywords: city, metropolis, management, intelligence, sustainable development, administrative law 